\title{
Observations of atmospheric chemical deposition to high Arctic snow
}

\author{
Katrina M. Macdonald ${ }^{1}$, Sangeeta Sharma ${ }^{2}$, Desiree Toom ${ }^{2}$, Alina Chivulescu ${ }^{2}$, Sarah Hanna ${ }^{3}$, Allan K. Bertram ${ }^{3}$, \\ Andrew Platt ${ }^{2}$, Mike Elsasser ${ }^{2}$, Lin Huang ${ }^{2}$, David Tarasick ${ }^{4}$, Nathan Chellman ${ }^{5}$, Joseph R. McConnell ${ }^{5}$, \\ Heiko Bozem $^{6}$, Daniel Kunkel ${ }^{6}$, Ying Duan Lei ${ }^{1}$, Greg J. Evans ${ }^{1}$, and Jonathan P. D. Abbatt ${ }^{7}$ \\ ${ }^{1}$ Department of Chemical Engineering and Applied Chemistry, University of Toronto, Toronto, M5S 3E5, Canada \\ ${ }^{2}$ Climate Research Divisions, Environment and Climate Change Canada, Toronto, M3H 5T4, Canada \\ ${ }^{3}$ Department of Chemistry, University of British Columbia, Vancouver, V6T 1Z1, Canada \\ ${ }^{4}$ Air Quality Research Divisions, Environment and Climate Change Canada, Toronto, M3H 5T4, Canada \\ ${ }^{5}$ Desert Research Institute, Reno, 89512, USA \\ ${ }^{6}$ Institute for Atmospheric Physics, Johannes Gutenberg University Mainz, Mainz, 55128, Germany \\ ${ }^{7}$ Department of Chemistry, University of Toronto, Toronto, M5S 3H6, Canada
}

Correspondence to: Jonathan Abbatt (jabbatt@chem.utoronto.ca)

Received: 23 October 2016 - Discussion started: 7 November 2016

Revised: 3 April 2017 - Accepted: 3 April 2017 - Published: 10 May 2017

\begin{abstract}
Rapidly rising temperatures and loss of snow and ice cover have demonstrated the unique vulnerability of the high Arctic to climate change. There are major uncertainties in modelling the chemical depositional and scavenging processes of Arctic snow. To that end, fresh snow samples collected on average every 4 days at Alert, Nunavut, from September 2014 to June 2015 were analyzed for black carbon, major ions, and metals, and their concentrations and fluxes were reported. Comparison with simultaneous measurements of atmospheric aerosol mass loadings yields effective deposition velocities that encompass all processes by which the atmospheric species are transferred to the snow. It is inferred from these values that dry deposition is the dominant removal mechanism for several compounds over the winter while wet deposition increased in importance in the fall and spring, possibly due to enhanced scavenging by mixed-phase clouds. Black carbon aerosol was the least efficiently deposited species to the snow.
\end{abstract}

\section{Introduction and background}

In recent decades drastic changes have been observed within the Arctic, including a rapid increase in surface temperatures and loss of sea ice and snow cover (Rigor et al., 2000;
Stroeve et al., 2005; Hartmann et al., 2013). Not only have these changes had adverse consequences for local populations and ecosystems, it has been suggested that their impacts may be significant at the global scale (Law and Stohl, 2007; AMAP, 2011). Light-absorbing compounds, the most widely studied of which being black carbon (BC) particles, can have a particularly significant impact on the Arctic atmosphere and snow systems through the absorption of solar radiation and subsequent warming and snowmelt (Bond et al., 2013). While the Arctic atmosphere has been previously explored spatially, temporally, and compositionally (e.g., Hartmann et al., 2013), Arctic snow and the mechanisms linking snow to the atmosphere have been the subject of only a relatively small number of studies (AMAP, 2011) despite the enormous amount of research conducted on the Arctic haze phenomenon (Quinn et al., 2007). Seasonal observations of fresh snow samples are particularly uncommon (e.g., Davidson et al., 1993; Toom-Sauntry and Barrie, 2002; Hagler et al., 2007) and previous explorations of snow deposition and scavenging mechanisms have been largely reliant on shortterm or aged snowpack sampling (e.g., Bergin et al., 1995), ice cores (e.g., Legrand and De Angelis 1995), modelling, and laboratory tests.

Aerosols entering the Arctic atmosphere, either generated locally or transported from elsewhere, can be removed 
by atmospheric transport or deposition. Deposition of particles follows two mechanisms: dry deposition, whereby particles are deposited to the ground by impaction, gravitational settling, and Brownian motion; and wet deposition, whereby particles are scavenged by hydrometeors and deposited through precipitation. Wet deposition is further split into two scavenging mechanisms: in-cloud scavenging, which removes particles from the cloud layer during precipitation formation, and below-cloud scavenging, which removes particles from the atmospheric column through which precipitation falls. Gaseous compounds also undergo similar scavenging processes (Seinfeld and Pandis, 2006).

The rate of dry deposition is dependent on the properties of the depositing particle, the surface onto which deposition occurs, and the air-surface boundary layer (Sehmel, 1980; Zhang and Vet, 2006). Dry deposition velocities of accumulation-mode particles, the dominant mass-weighted mode of particles observed in the non-summer Arctic (Sharma et al., 2013), to snow have been modelled and observed over a range of 0.01 to $0.60 \mathrm{~cm} \mathrm{~s}^{-1}$, typically within 0.02 to $0.10 \mathrm{~cm} \mathrm{~s}^{-1}$; gaseous deposition velocities to a snow surface show a similar range, with observations from 0.05 to $0.50 \mathrm{~cm} \mathrm{~s}^{-1}$ and a typical velocity of approximately $0.10 \mathrm{~cm} \mathrm{~s}^{-1}$ (McMahon and Denison, 1979; Sehmel, 1980; Davidson et al., 1985b, 1987; Hillamo et al., 1993; Bergin et al., 1995; Petroff and Zhang, 2010; Liu et al., 2011). Wet deposition is dependent on the properties of the depositing aerosol and the atmospheric conditions. In-cloud scavenging is largely controlled by a particle's size and composition, which dictate its ability to nucleate hydrometeors and to be scavenged by cloud droplets. Particles can act as cloud condensation nuclei $(\mathrm{CCN})$ that nucleate water droplets or ice nuclei (IN) that nucleate ice crystals. Common CCN components include sea salt, sulfate $\left(\mathrm{SO}_{4}^{2-}\right)$, and nitrate $\left(\mathrm{NO}_{3}^{-}\right)$, while mineral dust and bioaerosols are common IN (Hoose and Möhler, 2012; Farmer et al., 2015). Typically, BC is considered to be an ineffective CCN or IN (Hoose and Möhler, 2012; Farmer et al., 2015). Although liquid water clouds are not expected during the Arctic winter, mixed-phase clouds, which contain both liquid water and ice, have been observed in this region at temperatures well below $0^{\circ} \mathrm{C}$, in unusual cases down to $-40^{\circ} \mathrm{C}$ but more commonly between -20 and $-10^{\circ} \mathrm{C}$ (Morrison et al., 2005; Shupe et al., 2006). Belowcloud deposition is dependent on snow type and meteorological conditions, which dictate the volume of air scavenged per snowfall (Zhang and Vet, 2006). Particle size also affects below-cloud scavenging with higher scavenging efficiencies for particles above $2.5 \mu \mathrm{m}$ diameter relative to accumulationmode particles (Zhang and Vet, 2006). The total wet deposition is a function of the volume of precipitation. Hence, wet deposition is not typically described via a deposition velocity.

The goals of this paper are to present a new dataset in which the chemical composition of freshly fallen snow was measured through a fall-winter-spring period at a high Arc- tic field station. By combining these data with simultaneous measurements of ambient aerosol, the efficiency of deposition of individual species from the atmosphere to the snow can be evaluated under a set of broad assumptions. While this paper presents the measurement dataset in detail and focuses on the depositional and scavenging mechanisms that can be inferred from it, a subsequent publication will identify potential pollutant sources based on the snow compositional data. To our knowledge, this is the first time that the composition and flux of freshly fallen snow has been analyzed at high temporal frequency throughout an entire cold season in the high Arctic. All data from this study will be available upon conclusion of the NETCARE project via the Government of Canada Open Data Portal.

\section{Methodology}

\subsection{Snow sample collection}

Snow samples were collected at Environment and Climate Change Canada's (ECCC) Neil Trivett Global Atmosphere Watch Observatory at Alert, Nunavut, from 14 September 2014 to 1 June 2015 as part of the Network on Climate and Aerosols Research (NETCARE) initiative to create a temporally refined and broadly speciated dataset of high Arctic snow measurements. Alert is a remote outpost in the Canadian high Arctic, at the northern coast of Ellesmere Island $\left(82^{\circ} 27^{\prime} \mathrm{N}, 62^{\circ} 30^{\prime} \mathrm{W}\right)$, with a small transient population of research and military personnel (location details provided in the Supplement Sect. S4). Snow samples were collected from two Teflon-surfaced snow tables (about $1 \mathrm{~m}^{2}$ by $1 \mathrm{~m}$ above ground level, shown in Supplement Fig. S2) located in an open-air minimal traffic site, about $6 \mathrm{~km} \mathrm{SSW}$ of the Alert base camp, $201 \mathrm{~m}$ above sea level. Freshly fallen snow was collected from the tables using a Teflon scraper and scoop by dividing the table into rectangular portions for replicate sample collection. Four replicate samples were collected for this study and the table area cleared to fill each bottle was recorded. Prior to their first use and between snow sample collections, both snow tables were fully cleared of all remaining snow and cleaned with methanol. Samples were collected as soon after the end of each snowfall as feasible, conditions allowing. From 14 September 2014 to 1 June 2015, 59 sets of snow samples were collected. When insufficient snow volume was available for complete collection, a subset of the replicate samples was collected as listed in the Supplement Table S1. The interval between collections varied based on snowfall frequency, ranging from 1 to 19 days with an average of 4 days. The table area and collection period length associated with each sample allowed the measured concentration of each analyte to be converted to a flux. New sample bottles were used for the collection campaign and each bottle was thoroughly cleaned prior to use. Bottles and lids were soaked in $5 \%$ nitric acid, $1 \%$ detergent in water (Alconox), 
and deionized $18.2 \mathrm{M} \Omega$ water (DIW), allowing 10 to $14 \mathrm{~h}$ for each soak. Each dried bottle was then sealed in a protective plastic sleeve until use. At Alert, plastic outer gloves and lab coats were used to minimize contamination during collection, and the scraper and scoop were cleaned with DIW prior to each collection.

The collection of fresh snow samples reduces the impact of snow sublimation and/or melt as well as the movement of chemical species between snow and air, which can be a concern for snowpack sampling; however, some bidirectional exchange between snow and atmosphere is unavoidable within natural snowpack and still expected to smaller extent on the snow table. Also, the collection of samples from a snow table eliminated the difficulty in distinguishing the fresh stratigraphic snow layer from aged layers below, a source of uncertainty for traditional surface snow sampling. This ability to assign a well-defined deposition area and time period to each sample was an advantage over traditional sampling campaigns of aged snowpack. However, both this and traditional snow collection techniques are prone to the uncertainty introduced by the redistribution of snow by winds. Measurements of snowfall accumulation were not available for the collection site. Snow depths measured at the Alert ECCC station indicate that the snow collected on the tables may have underestimated the total snowfall volume by a factor of approximately 1 to 10 ; however, the meteorological station and collection site were separated by over $6 \mathrm{~km}$ with a $50 \mathrm{~m}$ difference in elevation, and there was significant disagreement between operator records of weather and that indicated by the meteorological station (see Sect. S4.2 for details). Thus, it was unclear whether this disagreement was the result of snow loss from the snow table or the natural spatial variability in precipitation, and no correction was applied to the collected snow depth. Furthermore, it should be noted that dry deposition via the filtration of air as it is pumped through the snowpack (as described in Harder et al., 1996) may differ between snow on a snow table and that on the surface.

\subsection{Campaign meteorological conditions}

Alert station operators recorded the collection conditions for each sample. Atypical snowfall events were noted: diamond dust events, small crystalline snowfalls, and blowing snow events, periods when high winds potentially resuspended snow from the ground. Operators also made note of any unusual weather conditions such as fog or blizzard conditions. Local ground-level meteorological conditions were monitored by the Alert ECCC stations, approximately $6 \mathrm{~km}$ NNE of the collection site (station IDs 2400306 , 2400305, and 2400302; retrieved November 2015 from climate.weather.gc.ca). In addition to ground-level meteorological information, vertical profiles were monitored via 6 to $12 \mathrm{~h}$ radiosondes. The radiosonde data were used to estimate mixing height and cloud height over the campaign. Mixing height was taken as the lowest altitude corresponding to an inflection point in the potential temperature. When the potential temperature gradient did not change from negative to positive within the lowest $3 \mathrm{~km}$, no mixing height was found. The vertical humidity profiles were used to identify cloud height as the lowest altitude, within $3 \mathrm{~km}$ of the surface, with $100 \%$ relative humidity. When $100 \%$ humidity was not reached, this criterion was relaxed to $95 \%$. Details of meteorology data are provided in Sect. S4.2.

\subsection{Snow sample preparation and analysis}

All snow samples were kept frozen prior to analysis, throughout storage and shipping. A broad suite of analytes was quantified using replicate snow samples from each snowfall: BC, major ions, and metals. Detailed procedures are provided in the Sect. S2.

Refractory BC quantification was completed via singleparticle soot photometry (SP2) as per McConnell et al. (2007). Briefly, melted and sonicated snow samples were atomized via Apex-Q nebulizer and dried particles with 0.02 to $50 \mathrm{fg} \mathrm{BC}$ were quantified via SP2. Observed BC mass distributions did not suggest significant underestimation of the total BC mass due to this size cut-off. A quality control standard and an analysis blank were analyzed for every batch of 17 samples.

Major ions were measured via ion chromatography (IC) at ECCC, as per Toom-Sauntry and Barrie (2002). Briefly, melted samples were quantified using a Dionex IC: DX600 for anions and cations and ICS2000 for organic acids. Aliquots of these samples were also used for $\mathrm{pH}$ analysis (Denver pH analyzer). Equipment was calibrated daily and quality control runs completed every 10 samples.

Metals analysis was completed via inductively coupled plasma mass spectrometry (ICP-MS) at the University of Toronto. Briefly, melted samples were filtered to separate insoluble and soluble metals (considered as that which was retained or passed through a $0.45 \mu \mathrm{m}$ cellulose acetate filter, respectively). Both filtrate and filter were digested using $70 \%$ nitric acid, ultra-trace grade (SCP Science PlasmaPure), and filter digestion was augmented using a microwave digester (CEM MARS 6). Centrifuged samples were then quantified via ICP-MS (Thermo Scientific iCAP Q). A performance test and calibration (SCP Science PlasmaCAL QC Std 4) were completed prior to each run, and quality control checks were completed every 10 samples. Also, an internal standard was included to quantify and correct for any instrument drift or inter-sample variability (SCP Science Int. Std. Mix 1). All sample preparation was completed in a class 100 vertical laminar flow cabinet (AirClean Systems AC 632).

Quality assurance is of the upmost importance in the analysis of dilute Arctic samples. Instrument accuracy was confirmed through the analysis of certified reference materials. The uncertainty of each measurement was estimated based on analysis detection limits and reproducibility; details are 
Table 1. Overview of fresh snow composition and inferred fluxes during the 2014 to 2015 winter season.

\begin{tabular}{|c|c|c|c|c|c|c|c|}
\hline \multirow[t]{2}{*}{ Analysis } & \multirow[t]{2}{*}{ Analyte } & \multicolumn{3}{|c|}{ Snow mixing ratio (ppb) } & \multicolumn{3}{|c|}{ Snow flux $\left(\mu \mathrm{g} \mathrm{m}^{-2} \mathrm{~d}^{-1}\right)$} \\
\hline & & 25th percentile & 50th percentile & 75th percentile & 25th percentile & 50th percentile & 75th percentile \\
\hline SP2 & $\mathrm{BC}$ & 1.3 & 2.3 & 4.1 & 0.24 & 0.42 & 0.86 \\
\hline \multirow[t]{14}{*}{ IC } & MS & $<1.9$ & $<1.9$ & 2.5 & $<0.1$ & $<0.1$ & $<0.1$ \\
\hline & ACE & 9.6 & 19.9 & 27.3 & 1.9 & 3.5 & 7.5 \\
\hline & PRP & $<1.5$ & 2.2 & 5.3 & $<0.10$ & 0.62 & 2.06 \\
\hline & FOR & 8.4 & 11.0 & 14.8 & 1.32 & 2.66 & 4.72 \\
\hline & $\mathrm{Cl}^{-}$ & 132 & 249 & 605 & 35.6 & 59.2 & 122.5 \\
\hline & $\mathrm{Br}^{-}$ & $<5.0$ & $<5.0$ & 12.1 & $<0.3$ & $<0.3$ & 2.0 \\
\hline & $\mathrm{NO}_{3}^{-}$ & 85.4 & 152.5 & 265.8 & 10.8 & 23.8 & 50.2 \\
\hline & $\mathrm{SO}_{4}^{2-}$ & 204 & 297 & 554 & 32.4 & 69.9 & 132.5 \\
\hline & $\mathrm{C}_{2} \mathrm{O}_{4}^{2-}$ & $<18.0$ & $<18.0$ & 20.8 & $<1.2$ & 0.2 & 2.7 \\
\hline & $\mathrm{Na}^{+}$ & 55.4 & 110.7 & 237.9 & 10.9 & 20.1 & 52.4 \\
\hline & $\mathrm{NH}_{4}^{+}$ & 10.6 & 12.4 & 16.6 & 1.3 & 2.5 & 5.9 \\
\hline & $\mathrm{K}^{+}$ & 8.0 & 15.4 & 23.5 & 0.8 & 2.0 & 3.9 \\
\hline & $\mathrm{Mg}^{2+}$ & 22.3 & 43.3 & 77.4 & 2.2 & 7.6 & 13.3 \\
\hline & $\mathrm{Ca}^{2+}$ & $<133.1$ & 193.1 & 409.2 & $<9.1$ & 14.6 & 51.5 \\
\hline & $\mathrm{H}^{+}$ & 1.39 & 4.25 & 6.97 & 0.25 & 0.88 & 1.87 \\
\hline analyzer & $(\mathrm{pH})$ & $(5.16)$ & $(5.37)$ & (5.86) & $\mathrm{n} / \mathrm{a}$ & $\mathrm{n} / \mathrm{a}$ & $\mathrm{n} / \mathrm{a}$ \\
\hline \multirow[t]{12}{*}{ ICP-MS } & $\mathrm{Mg}$ & 18.2 & 28.6 & 67.6 & 3.0 & 6.5 & 14.5 \\
\hline & $\mathrm{Al}$ & $<3.2$ & 7.2 & 19.2 & $<0.2$ & 1.4 & 3.3 \\
\hline & V & 0.006 & 0.012 & 0.086 & 0.002 & 0.003 & 0.014 \\
\hline & $\mathrm{Mn}$ & 0.23 & 0.64 & 1.14 & 0.06 & 0.10 & 0.20 \\
\hline & $\mathrm{Fe}$ & 3.6 & 10.8 & 29.1 & 0.5 & 2.0 & 3.9 \\
\hline & Co & $<0.002$ & 0.004 & 0.011 & $<0.0002$ & 0.0007 & 0.0015 \\
\hline & $\mathrm{Cu}$ & $<0.02$ & 0.05 & 0.28 & 0.001 & 0.010 & 0.053 \\
\hline & As & 0.007 & 0.044 & 0.071 & 0.002 & 0.006 & 0.013 \\
\hline & $\mathrm{Se}$ & 0.010 & 0.024 & 0.058 & 0.002 & 0.004 & 0.010 \\
\hline & $\mathrm{Sb}$ & 0.004 & 0.010 & 0.018 & 0.001 & 0.002 & 0.004 \\
\hline & $\mathrm{Tl}$ & $<0.0001$ & 0.0001 & 0.0004 & $<7.2 \times 10^{-6}$ & $15.6 \times 10^{-6}$ & $54.0 \times 10^{-6}$ \\
\hline & $\mathrm{Pb}$ & 0.05 & 0.25 & 0.41 & 0.012 & 0.039 & 0.086 \\
\hline
\end{tabular}

Notes: BC is black carbon; MS is methanesulfonate; ACE is acetate; PRP is propionate; FOR is formate. $<$ no. indicates measurement is below MDL. $\mathrm{n} / \mathrm{a}=$ not applicable.

provided in Sect. S2 (as per Reff et al., 2007; Norris et al., 2014). Also, the signal-to-noise ratio $(\mathrm{S} / \mathrm{N})$ of each analyte was calculated to indicate the strength of each measurement, with a $\mathrm{S} / \mathrm{N}$ value over one considered to be strong (Norris et al., 2014). Regular analysis of blanks was used for background subtraction and to define method detection limits (MDL) as 3 standard deviations of the blank levels. Beyond typical preparation blanks, which used DIW in the place of snow meltwater, field blanks were also analyzed. Once per month, a set of empty sample bottles was brought to the snow table, opened, and resealed without collection. These field blank bottles were stored and shipped with the regular samples and rinsed with DIW to quantify any contamination throughout the sampling process. Any influence from the local Alert base camp was identified using local wind records and the activity logs of the base camp personnel. The only analytes that showed a potential influence from base camp winds were crustal metals, with Pearson's correlation coefficients $(R)$ of 0.4 to 0.6 ( $p$ value 0.0001 to 0.002 ) between snow mixing ratios and periods of base camp winds. Base camp combustion activity logs showed no significant impact on the samples.

\subsection{Atmospheric monitoring}

Ground-level atmospheric monitoring data from the Alert Global Atmospheric Watch Observatory were provided by ECCC (see Sect. S3 for details). Atmospheric BC was monitored hourly by SP2 (Droplet Measurement Technology) (as per Schroder et al., 2015) and major ions by IC of 6 to 8-day high-volume filters of total suspended particles ( $\mathrm{Hi}-\mathrm{Vol}$ ) (as per Sirois and Barrie, 1999). Both the SP2 and Hi-Vol were operational throughout the campaign with coverages of 92 and $94 \%$, respectively. 


\subsection{Transport modelling}

The Lagrangian particle dispersion model FLEXPART (Stohl et al., 2005) was used to determine the source region of air masses that were measured over Alert. This model has previously been shown to be an effective tool for the prediction of transport pathways into and within the Arctic (e.g., Paris et al., 2009). The simulations were driven using meteorological analysis data from the European Centre for Medium-Range Weather Forecasts with a horizontal grid spacing of $0.25^{\circ}$ in longitude and latitude and 137 levels in the vertical. For each 5-day period during the measurement period we released virtual tracers over Alert in four different altitude levels, 100, 500, 1000, and $2000 \mathrm{~m}$ above sea level, to distinguish the levels which may be scavenged by snow. The tracers were then followed for 10 days backward to obtain the source region for the particular time period. The FLEXPART results were used to explore the dominant source regions associated with each sample. As a simple quantification of the variability in source region, FLEXPART trajectories were summarized by the observed southern limit of transport. This southern limit was calculated as the latitude, which encircles $98 \%$ of the 10-day transport source area. Values were calculated using each of the four initialization altitudes.

\section{Results and discussion}

\subsection{Total deposition of Arctic snowfall events}

Each sample for this study was collected fresh after a known time and over a known area. Given that the snow tables were exposed to the ambient atmosphere for the entirety of each collection period, the measured deposition is considered to represent the total deposition (wet and dry) for said period; however, it is known that surrogate surfaces do not provide an exact proxy for the deposition, which would be seen to a natural snow surface (Ibrahim et al., 1983; Davidson et al., 1985a; Hicks, 1986). There are two additional caveats to this assumption. Firstly, dry deposition at the beginning of each period would fall directly on the exposed clean table rather than onto previously deposited snow. It is unknown what impact these different surface characteristics could have had on the initial deposition rate and collection efficiency. Thus, there is additional uncertainty in the capture of initial dry deposition to the bare table. Secondly, strong winds can disturb and redistribute the snowpack and cause snow to be blown off and/or onto the snow table. Alert operators recorded four occasions when the snowpack was observed to be resuspended due to high winds and these were excluded from the presented results. The dates of these blowing snow events are noted in Table $\mathrm{S} 1$ as are missed collections.

The observed snow mixing ratios and fluxes are summarized in Table 1 and Fig. 1 for measured analytes with a strong $\mathrm{S} / \mathrm{N}$. Mixing ratio is reported as parts per billion by mass (ppb) with the exception of $\mathrm{pH}$. Flux is reported on a per day basis to take into account the differing collection period lengths; however, it should be noted that this length corresponds to the entire collection period (i.e., the number of days between clearing the snow table), not just the length of time when snow was actually falling. A full record of the measured deposition over the campaign is provided in the Supplement (Tables S1-S6) along with the associated uncertainties and notes of atypical collection conditions. It should be noted that although IC measurements are provided as the measured ions throughout the discussion, these analytes may not necessarily exist in the dissociated ionic form in the environment. Also, the metal measurements provided in Table 1 are total values, insoluble and soluble. The soluble fractions differed by analyte and by date and are provided in the Supplement (Tables S4-S6). The metal measurements can be roughly classified into three categories: predominantly insoluble analytes $\mathrm{Fe}$ and $\mathrm{Al}$ (>50\% insoluble over full campaign); variably soluble/insoluble analytes $\mathrm{Co}, \mathrm{V}, \mathrm{As}, \mathrm{Cu}, \mathrm{Pb}$, $\mathrm{Mn}, \mathrm{K}$, and $\mathrm{Mg}$; and predominantly soluble analytes $\mathrm{Ca}$ and $\mathrm{Na}(<50 \%$ insoluble) (in order from least to greatest average soluble fraction), excluding analytes with insufficient soluble or insoluble measurements above MDL.

A review of existing Arctic snow measurements found the measured median mixing ratios to fall within expected ranges (see Table S5 for details); however, it should be noted that the referred data represent a variety of collection and analysis techniques. In general, measurements of this campaign showed salt species and non-crustal metals to be at the lower end of the typical range while $\mathrm{SO}_{4}^{2-}$ and $\mathrm{NO}_{3}^{-}$were at the higher end. A limited number of seasonal snow collection campaigns were available for comparison of the observed seasonal trend in analytes. The winter peak in BC was similar to that observed by Davidson et al. (1993); however, spring values observed in this campaign were higher than previously seen. The observed seasonal trend in major ions was generally consistent with existing literature (Davidson et al., 1993; Toom-Sauntry and Barrie, 2002; Dibb et al., 2007). Specifically, a winter peak in sea salt, fall/spring peaks in $\mathrm{MS}$, and a winter peak in $\mathrm{NO}_{3}^{-}$are all typical. However, the fall peak observed in the non-sea-salt (NSS) $\mathrm{SO}_{4}^{2-}$ mixing ratio and spring peak in $\mathrm{NO}_{3}^{-}$were unlike seasonal trends observed previously (Davidson et al. 1993; Toom-Sauntry and Barrie, 2002). Unusual weather events, as noted by the operators, are highlighted in Fig. 1; however, no obvious relationship was observed with snow measurements, with the exception of blizzard and high wind conditions in January and February, which were associated with elevated mixing ratios for several chemical species. Atmospheric measurements are provided in the Table S7. As observed for snow, most atmospheric analytes experienced a winter high. The fall/spring peaks in MS and notable fall peak in $\mathrm{SO}_{4}^{2-}$ persisted in both snow and atmospheric measurements. 


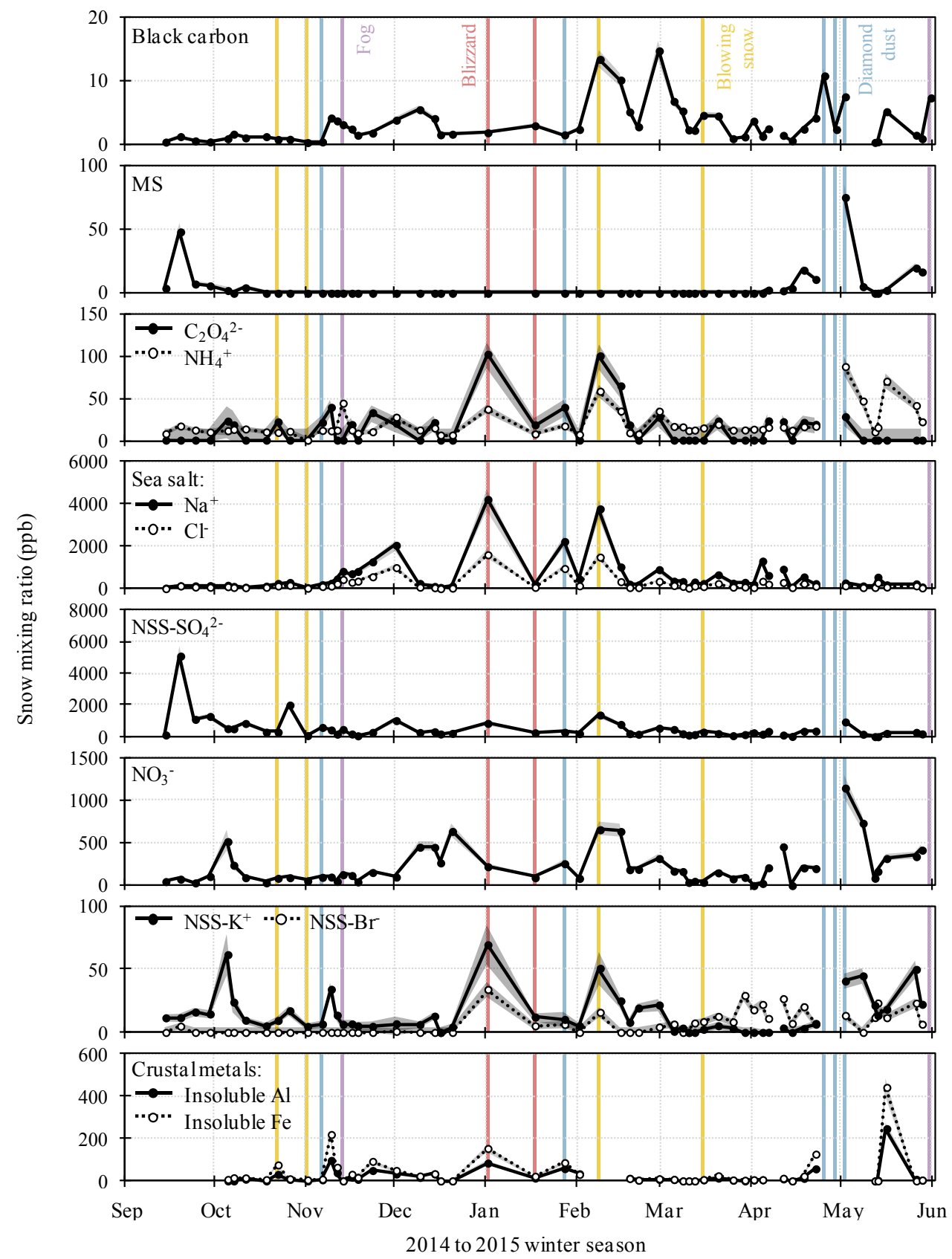

Figure 1. Measured snow mixing ratio (line) and uncertainty (shaded area) of key analytes during 2014 to 2015 campaign.

\subsection{Factors influencing snow scavenging and deposition}

\subsubsection{Effective deposition velocity}

As discussed above, the collected snow samples provide information on the total deposition of material to the surface over a given time and area. In order to elucidate the mechanisms controlling this bulk deposition, a simplistic model for flux, Eq. (1), was adopted to describe the measured deposi- tion:

$$
F_{\mathrm{S}, \text { total }}^{i j}=C_{\mathrm{A}}^{i j} v_{\mathrm{d}, \mathrm{eff}}^{i j}
$$

where $F_{\mathrm{S}, \text { total }}^{i j}$ is the flux deposited to snow of the $j$ th analyte over the $i$ th period, $C_{\mathrm{A}}^{i j}$ is the arithmetic average atmospheric concentration, and $v_{\mathrm{d} \text {,eff }}^{i j}$ is the effective deposition velocity.

The measured snow flux $\left(F_{\mathrm{S}, \text { total }}\right)$ represents the total deposition by wet and dry mechanisms. Thus, the effective deposition velocity $\left(v_{\mathrm{d}, \text { eff }}\right)$ encompasses the variety of aerosol 
and meteorological properties controlling deposition efficiency and the relative importance of each deposition pathway: dry, wet in-cloud, and wet below-cloud scavenging. This effective velocity is akin to a typical deposition velocity; however, it encapsulates the bulk movement of material by combining the dry deposition velocity and the wet deposition efficiency as an equivalent velocity. Thus, this parameter can be used to provide a holistic view of Arctic deposition. Use of the effective deposition velocity also avoids the uncertainties of estimating the split between dry and wet deposited mass. A caveat to this analysis is that the three deposition mechanisms relate to different atmospheric concentrations, a gradient which is not necessarily captured when the groundlevel atmospheric concentration $\left(C_{\mathrm{A}}\right)$ is used to calculate the effective deposition velocity: dry deposition affects the lower atmosphere, in-cloud scavenging the cloud layer, and belowcloud scavenging the full below-cloud atmospheric column. Previous observations of vertical profiles in the Arctic have shown notable variability with altitude (Hansen and Rosen, 1984; Leaitch et al., 1989; Spackman et al., 2010; Brock et al., 2011; Sharma et al., 2013). So, the calculated effective velocity includes an intrinsic variability dependent on the vertical atmospheric profile of each analyte.

Effective deposition velocities were calculated for chemical species measured in both snow (SP2 and IC) and atmospheric (SP2 and Hi-Vol) samples. Figure 2 shows effective deposition velocities calculated as the ratio of total summed snow flux and average atmospheric concentration measured over the same period. Both a 6-day resolution, as per the Hi-Vol sampling frequency, and monthly resolution are provided. The calculated effective deposition velocities ranged from 0.001 to $10 \mathrm{~cm} \mathrm{~s}^{-1}$ ( 0 to $16 \mathrm{~cm} \mathrm{~s}^{-1}$ with uncertainty). Episodic and monthly peaks are observed in Figure 2 for each analyte. The variance in deposition observed by composition and temporally is discussed below.

\subsubsection{Variation in deposition by composition}

Monthly effective deposition velocities were used to contrast deposition mechanisms by aerosol composition. A monthly resolution provides insight into the general deposition regime of each analyte, highlighting the impact of bulk deposition characteristics rather than event-specific variability. The variability between aerosol of different composition and the influences of seasonal changes within the Arctic system are simpler to identify without the interference of variability across event-specific conditions. A monthly analysis also facilitates future comparison with modelled results which may not replicate individual events. January and February 2015, were excluded from the monthly analysis because blizzard and high wind conditions were believed to have caused significant losses of snow from the snow tables during these months (based on operator reports), which would lead to underestimation of these snow flux values. The effective deposition velocity is best suited to analysis across periods of equal length and precipitation volume, since both of these parameters are inherently included when the wet deposition efficiency is converted to an equivalent deposition velocity. With the exception of January and February, the total monthly snow precipitation over the campaign was relatively constant, with a relative standard deviation of $20 \%$.

Figure 3 shows that the typical deposition characteristics varied by analyte, with median effective deposition velocities ranging from 0.03 to $1.1 \mathrm{~cm} \mathrm{~s}^{-1}$; however, error bars describing the combined uncertainty of the snow and atmospheric measurements show that the range of calculated effective deposition velocities of each analyte have considerable overlap. The calculated monthly effective deposition velocities showed a relative standard deviation of 60 to $150 \%$ across the measured analytes, while measurement-based uncertainty was estimated as only $\pm 35 \%$, indicating a significant impact of aerosol state or properties on deposition.

The variability observed across analytes may be the result of variations in aerosol properties. First, the measured chemical species differ in terms of dominant phase: $\mathrm{BC}$, ammonium $\left(\mathrm{NH}_{4}^{+}\right), \mathrm{SO}_{4}^{2-}, \mathrm{Na}^{+}, \mathrm{K}^{+}, \mathrm{Mg}^{2+}$, oxalate $\left(\mathrm{C}_{2} \mathrm{O}_{4}^{2-}\right)$, and $\mathrm{Ca}^{2+}$ are typically observed predominantly in the particle phase within the Arctic, while $\mathrm{MS}, \mathrm{Br}^{-}, \mathrm{Cl}^{-}$, and $\mathrm{NO}_{3}^{-}$and their associated precursors can have appreciable gas-phase portions (Barrie and Hoff, 1985). In general, analytes considered to be dominantly particle-based were seen to exhibit lower deposition velocities than those which may have existed as gases. This observation is supported by a detailed study of sea salt species. The $\mathrm{Cl}$ in salt particles has been previously observed to partition to the gas phase over winter months (e.g., Barrie and Hoff, 1985; Toom-Sauntry and Barrie, 2002; Quinn et al., 2009); thus, Arctic salt particles often show a $\mathrm{Cl}$ deficit while gaseous $\mathrm{Cl}$ shows enhancement. Such a process was corroborated by comparison of the atmospheric Hi-Vol and snow IC measurements for $\mathrm{Na}^{+}$and $\mathrm{Cl}^{-}$. Both atmospheric and snow measurements showed strong correlation of $\mathrm{Na}^{+}$and $\mathrm{Cl}^{-}$analytes, 0.92 and 0.99 , respectively. However, the ratio of $\mathrm{Cl}^{-} / \mathrm{Na}^{+}$differed between measurement mediums with a higher proportion of $\mathrm{Cl}^{-}$observed in snow $\left(\mathrm{Cl}^{-} / \mathrm{Na}^{+}=2.49\right.$ mass $/$ mass $)$ than in atmosphere $\left(\mathrm{Cl}^{-} / \mathrm{Na}^{+}=1.36\right)$. Compared to the typical marine ratio $\left(\mathrm{Cl}^{-} / \mathrm{Na}^{+}=1.795\right.$; Pytkowicz and Kester, 1971), the atmosphere showed a deficit in $\mathrm{Cl}^{-}$while snow showed enhanced $\mathrm{Cl}^{-}$(see Fig. S4). It is expected that the Hi-Vol measurement technique would collect predominantly atmospheric particles, while snow would scavenge both gaseous and particulate aerosol. Thus, the enhanced $\mathrm{Cl}^{-}$in snow above that of sea salt indicates that $\mathrm{Cl}$ partitioned to the gas phase, that both phases deposited to snow, and that gasphase $\mathrm{Cl}$ was scavenged to snow preferentially. Assuming all $\mathrm{Na}^{+}$and $\mathrm{Cl}^{-}$originated as sea salt particles, the $\mathrm{Cl}^{-}$ mass from each phase can be estimated in the atmosphere and snow. Based on these estimated proportions in the snow and atmosphere, median effective deposition velocities were 

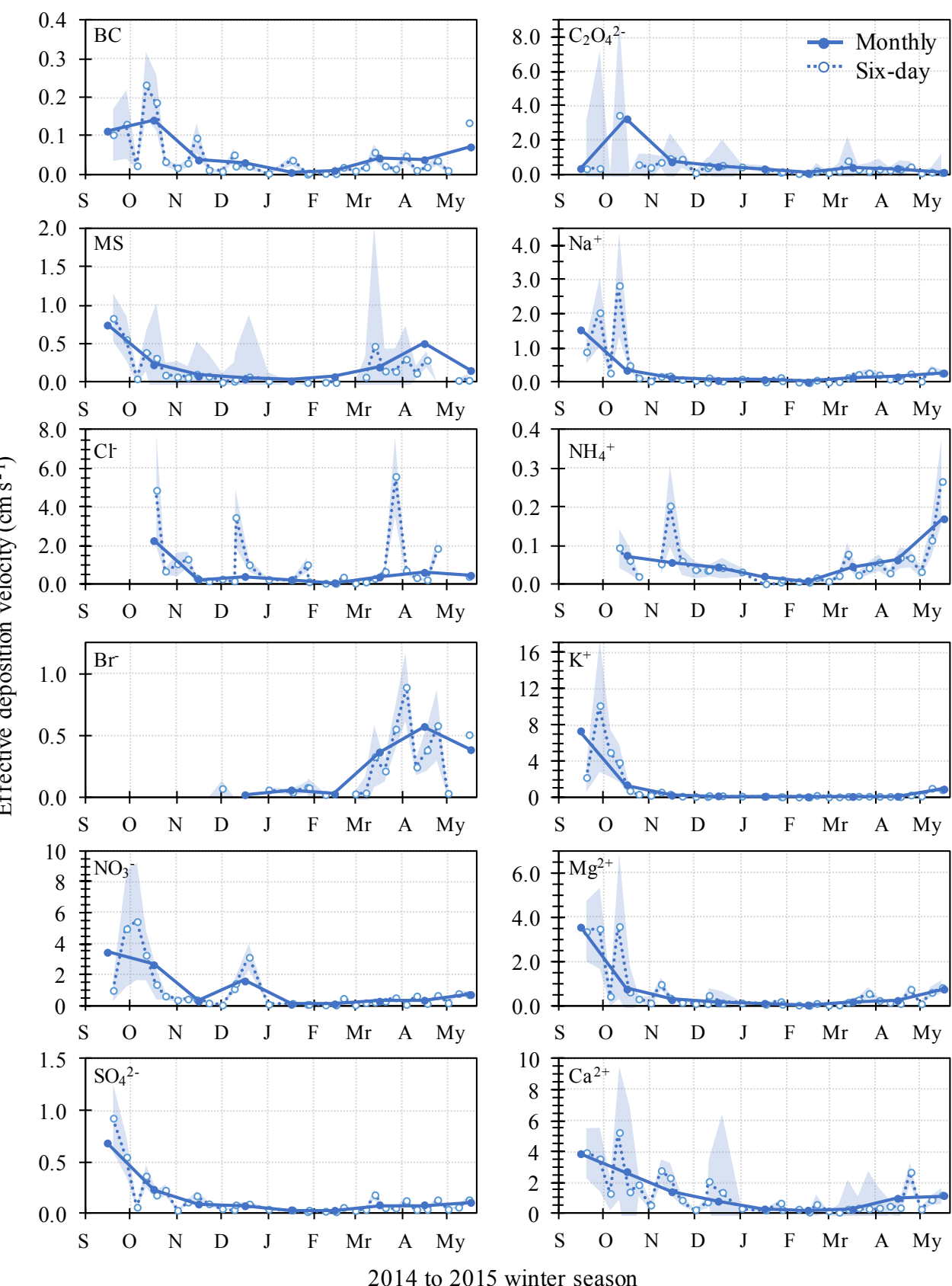

Figure 2. Effective deposition velocity at monthly (solid) and approximately 6-day (dashed) frequencies with 6-day uncertainties (shaded area). Missing values indicate periods with snow and/or atmospheric measurements below detection limits.

calculated as 0.16 and $0.40 \mathrm{~cm} \mathrm{~s}^{-1}$ for the particle and gas phases, respectively. Comparison of these velocities indicates an $86 \%$ enhancement in gas-phase deposition relative to that of the particle phase. Thus, gaseous scavenging may contribute to the enhanced bulk deposition observed in $\mathrm{MS} \mathrm{Br}^{-}$, $\mathrm{Cl}^{-}$, and $\mathrm{NO}_{3}^{-}$.

Particle nucleation affinity may also be a significant contributor to the observed differences in bulk deposition. The lowest velocities were observed for $\mathrm{BC}, \mathrm{NH}_{4}^{+}$, and $\mathrm{SO}_{4}^{2-}$, which largely fell within the typical range of deposition velocities seen for dry deposition: 0.02 to $0.10 \mathrm{~cm} \mathrm{~s}^{-1}$ for typical accumulation-mode Arctic particles (Davidson et al., 1987; Petroff and Zhang, 2010), as highlighted in Fig. 3. In contrast, the monthly velocities of other particle-dominated chemical species, $\mathrm{Na}^{+}, \mathrm{K}^{+}, \mathrm{Mg}^{2+}, \mathrm{C}_{2} \mathrm{O}_{4}^{2-}$, and $\mathrm{Ca}^{2+}$, all fell above the typical dry deposition range. Particles containing these analytes, as well as $\mathrm{NH}_{4}^{+}$and $\mathrm{SO}_{4}^{2-}$, have been previously suggested to act as better precipitation nuclei than $\mathrm{BC}$ 


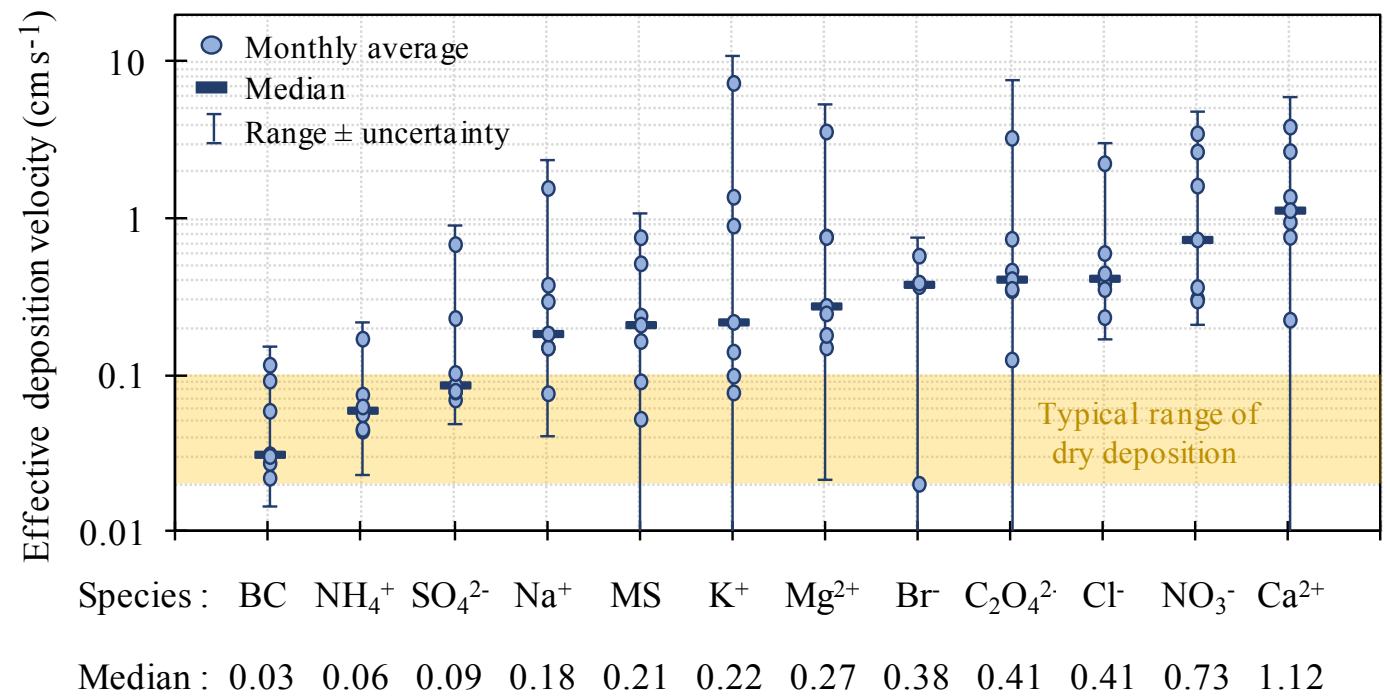

Figure 3. Monthly effective deposition velocities by composition (points, excluding January and February). The median of each analyte (bar) and full range with uncertainty (error bar) are also shown. Also shown is the typical range of dry deposition velocity for accumulation-mode particles to snow by others (Davidson et al., 1987; Petroff and Zhang, 2010).

(e.g., Zobrist et al., 2006; Hoose and Möhler, 2012; Farmer et al., 2015); thus, their enhanced velocities might be attributed to in-cloud scavenging. Thus, dry deposition may be the dominant deposition mechanism in some measurements while others show enhanced deposition which likely reflects an increased contribution of wet deposition processes. The observed difference in deposition velocities also implies that $\mathrm{BC}$-, $\mathrm{SO}_{4}^{2-}$-, and $\mathrm{NH}_{4}^{+}$-containing particles are to a significant extent externally mixed from these other constituents.

Furthermore, salt and crustal particles may experience enhanced deposition since they typically consist of coarser particles than $\mathrm{BC}, \mathrm{SO}_{4}^{2-}$, and $\mathrm{NH}_{4}^{+}$. Specifically, coarse-mode particles can exhibit dry deposition velocities to snow up to $0.6 \mathrm{~cm} \mathrm{~s}^{-1}$ and below-cloud scavenging efficiencies enhanced over accumulation-mode particles by a factor of 10 (Zhang and Vet, 2006; Petroff and Zhang, 2010). The enhancement of $\mathrm{Ca}^{2+}$ above other crustal-related analytes is unexpected. This cannot be satisfactorily explained without further study; however, the phenomenon may be connected to the dissimilar sources of Ca-rich mineral dust to that of other crustal species suggested by other studies (Banta et al., 2008). In addition to aerosol phase, nucleation affinity, and size as discussed above, particle coating could also impact the scavenging and deposition process. However, the potential influence of coatings on the observed velocities cannot be addressed with the available information.

\subsubsection{Temporal variability of deposition}

Shared temporal trends in effective deposition velocity can be observed in Fig. 2. A general trend of heightened deposition in the fall and spring can be observed across all analytes. In particular, $\mathrm{BC}, \mathrm{Na}^{+}, \mathrm{Mg}^{2+}$, and $\mathrm{Ca}^{2+}$ can be seen to share a similar seasonal and episodic trend, with Pearson's correlation coefficients of 0.7 to 0.9 (comparing 6-day resolution, excluding January and February 2015, $p$ values $<0.001$ ). Episodic peaks in $\mathrm{Mg}^{2+}$ and $\mathrm{Ca}^{2+}$ also show some similarity to $\mathrm{SO}_{4}^{2-}$ (correlation of $0.70-0.85, p$ value $<0.001$ ). The trend of $\mathrm{NH}_{4}^{+}$is more difficult to distinguish as September measurements were below detection limit; however, fall and spring peaks are suggested. A more pronounced fall peak was observed in $\mathrm{SO}_{4}^{2-}, \mathrm{Na}^{+}, \mathrm{K}^{+}$, and $\mathrm{Cl}^{-}$, though their episodic peaks differ. Although $\mathrm{MS}$ is distinguished by a spring peak, $\mathrm{MS}$ and $\mathrm{SO}_{4}^{2-}$ share similar episodic peaks with a 6-day correlation of 0.86 ( $p$ value $<0.001)$. The seasonal trends of $\mathrm{Br}^{-}, \mathrm{C}_{2} \mathrm{O}_{4}^{2-}$, and $\mathrm{NO}_{3}^{-}$are more distinct: $\mathrm{Br}^{-}$exhibits a broad spring peak, $\mathrm{C}_{2} \mathrm{O}_{4}^{2-}$ a short October peak, and $\mathrm{NO}_{3}^{-}$a broad fall/winter peak. Episodic $\mathrm{C}_{2} \mathrm{O}_{4}^{2-}$ showed moderate correlation with $\mathrm{BC}, \mathrm{Na}^{+}, \mathrm{Mg}^{2+}$, and $\mathrm{Ca}^{2+}$ (coefficient $=0.5-0.7, p$ value $<0.02)$ and $\mathrm{NO}_{3}^{-}$episodes showed correlation with $\mathrm{K}^{+}$(coefficient $=0.83, p$ value $<0.001$ ). There are some peak events shared across several analytes; for example, an early October peak is observed in most chemical species. While the differing magnitudes of effective deposition velocities observed across analytes imply separate scavenging and deposition, these shared temporal trends indicate that the externally mixed particles and gaseous chemical species are subject to similar temporal influences controlling deposition.

Several factors controlling deposition experience seasonal variations, which may have contributed to the observed intermonthly variability. Six properties of the Arctic system with seasonal trends were considered as possible influences on the observed velocity trend: precipitation, temperature, mixing height, cloud height, dominant aerosol source region, and 


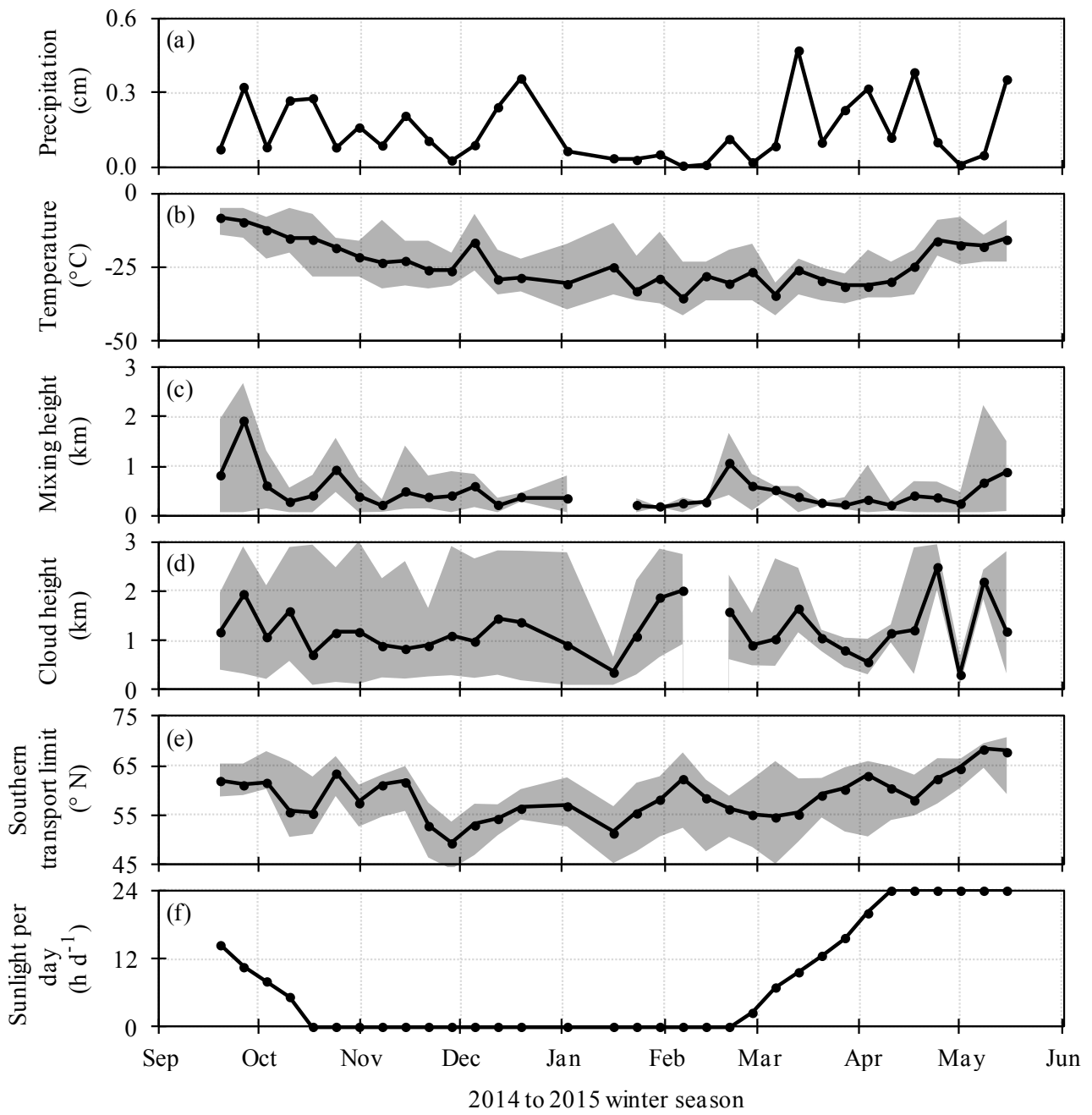

Figure 4. Seasonal variation in precipitation (a), temperature (b), mixing height (c), cloud height (d), transport (e), and sunlight (f). Precipitation and sunlight are presented as the average per snow sample collection period. Temperature, mixing/cloud height, and southern transport limit are presented as the average for each collection period (line) along with the full range (shaded area).

sunlight availability, as shown in Fig. 4. The precipitated snow-water equivalent depth was calculated from the snow mass and table area of each sample. Temperature was monitored at local ground-level meteorological stations over the campaign (Table S9) and sunlight estimated from location and time of year. The dominant aerosol source of each month was described using the southern limit to transport and mixing/cloud heights were estimated from radiosonde data, as described above.

Temperature, transport, and sunlight can be seen to follow similar seasonal trends with fall/spring peaks. Precipitation, mixing height, and cloud height exhibit episodic peaks and a less significant seasonal trend (intra-monthly relative standard deviation was a factor of 1.5 to 2 times higher than inter-monthly, whereas these values were approximately equal for temperature, transport, and sunlight). When compared to effective deposition velocities, $\mathrm{BC}, \mathrm{SO}_{4}^{2-}, \mathrm{Na}^{+}$,
$\mathrm{Mg}^{2+}, \mathrm{NO}_{3}^{-}$, and $\mathrm{Ca}^{2+}$ show better correlation with temperature than the other meteorological conditions shown in Fig. 4, with Pearson's correlation coefficients above 0.5 (excluding January and February 2015, $p$ value $<0.02$ ). Specifically, $\mathrm{SO}_{4}^{2-}, \mathrm{K}^{+}, \mathrm{Mg}^{2+}$, and $\mathrm{Ca}^{2+}$ had strong correlation coefficients with temperature of 0.6-0.7 ( $p$ values $<0.002$ ). Medium to high correlations were observed between mixing height and $\mathrm{SO}_{4}^{2-}, \mathrm{Na}^{+}, \mathrm{K}^{+}, \mathrm{Mg}^{2+}$, and $\mathrm{NO}_{3}^{-}$, with coefficients of 0.4-0.7 (highest correlation for $\mathrm{K}^{+}$at 0.76 ) and $p$ values below 0.05 . Bromide deposition showed strong correlation with sunlight (coefficient: $0.6, p$ value: 0.001 ). In contrast, $\mathrm{NH}_{4}^{+}$and MS showed only weak correlation with the described meteorological parameters (maximum coefficients of about 0.4 with transport and mixing height, respectively). In contrast, $\mathrm{C}_{2} \mathrm{O}_{4}^{2-}$ and $\mathrm{Cl}^{-}$did not show strong correlations with any of the described meteorological parameters (coefficients below 0.2). Overall, temperature showed 
the best correlation with deposition velocities for most analytes, followed by mixing height. Thus, changes in temperature may be linked to seasonal changes in the dominant scavenging mechanism of several analyzed species. Specifically, it is hypothesized that the increased presence of mixed-phase clouds with warmer temperatures may have enhanced wet deposition via in-cloud scavenging due to $\mathrm{CCN}$ activity for those analytes expected to exist predominantly in the particle phase: $\mathrm{BC}, \mathrm{NH}_{4}^{+}, \mathrm{SO}_{4}^{2-}, \mathrm{Na}^{+}, \mathrm{K}^{+}, \mathrm{Mg}^{2+}, \mathrm{NO}_{3}^{-}$, and $\mathrm{Ca}^{2+}$. This aligns with seasonal trend in $\mathrm{SO}_{4}^{2-}$ deposition observed by Davidson et al. (1985b, 1987) and the suggested link to deposition mechanism.

The effective deposition velocities for warmer and colder months were separated using a $-20^{\circ} \mathrm{C}$ cut-off between icecloud-dominated periods, November to April (N/D/Mr/A), and months with a significant potential for mixed-phase clouds, September, October, and May (S/O/My). Radiosonde observations show temperatures at typical cloud heights usually above $-20^{\circ} \mathrm{C}$ in $\mathrm{S} / \mathrm{O} / \mathrm{My}$ and below $-20^{\circ} \mathrm{C}$ in N/D/Mr/A, supporting the mixed-phase cloud hypothesis. Comparison of the effective deposition velocities delineated by these periods minimized the influence of precipitation volume as it was relatively constant: an average of $12 \mathrm{~mm} \mathrm{month}^{-1}$ in S/O/My and $18 \mathrm{~mm} \mathrm{month}^{-1}$ in $\mathrm{N} / \mathrm{D} / \mathrm{Mr} / \mathrm{A}$. However, the influence of aerosol source may differ by period given their distinct source profiles: longrange transport dominated in N/D/Mr/A and local transport dominated in S/O/My. Figure 5 depicts the range of effective deposition velocities calculated for each analyte over these two periods (again excluding January and February). Bromide was excluded from this analysis since it was below detection limit in the snow and/or atmospheric measurements from September to November.

With the exception of $\mathrm{C}_{2} \mathrm{O}_{4}^{2-}$, all analytes showed a larger median effective deposition velocity for the warmer S/O/My months than the colder N/D/Mr/A months. Although insufficient data are available to confirm the statistical significance for each individual analyte, the combined normalized dataset of velocities showed significant enhancement during S/O/My using the ANOVA test ( $p$ value $4.9 \times 10^{-8}$ ). Specifically, marked enhancement was seen for $\mathrm{BC}, \mathrm{NH}_{4}^{+}, \mathrm{SO}_{4}^{2-}, \mathrm{Na}^{+}$, $\mathrm{K}^{+}$, and $\mathrm{Mg}^{2+}$. The cold month deposition of these analytes can largely be described by dry deposition alone with velocities below $0.1 \mathrm{~cm} \mathrm{~s}^{-1}$ for analytes expected to be dominated by accumulation-mode particles and $0.6 \mathrm{~cm} \mathrm{~s}^{-1}$ for those expected to include significant coarse-mode mass; however, their warm month effective deposition velocities were a factor of 2 to 12 higher.

The unexpected discrepancy in the deposition of $\mathrm{Ca}^{2+}$ and $\mathrm{Mg}^{2+}$ given their typically similar origins, as discussed above, was also observed when comparing median warm and cold month periods. Both $\mathrm{Mg}^{2+}$ and $\mathrm{Ca}^{2+}$ are common to sea salt and crustal origins but their NSS portions can be estimated based on typical sea salt ratios with $\mathrm{Na}^{+}$(Pytkowicz and Kester, 1971). The NSS-Mg ${ }^{2+}$ and NSS-Ca ${ }^{2+}$ showed similar behaviour over the warm months, with average velocities of 2.4 and $2.6 \mathrm{~cm} \mathrm{~s}^{-1}$, respectively, but a larger difference in the cold months, with average velocities of 0.4 and $1.0 \mathrm{~cm} \mathrm{~s}^{-1}$, respectively. No explanation of this discrepancy can be supported without further study; however, it appears that $\mathrm{Ca}^{2+}$ and $\mathrm{Mg}^{2+}$ exist as externally mixed Ca-rich and Mg-rich crustal particles, which are subject to differing deposition processes, particularly in dry-deposition-dominated colder months.

Thus, the observed effective deposition velocities suggest that most analytes and particularly those expected to exist primarily as particle phase were preferentially scavenged during the warmer S/O/My months, possibly due to the presence of mixed-phase clouds and the associated CCN activation of these chemical species or enhanced belowcloud deposition of those compounds typically associated with larger particles. However, the change in source profile typically experienced during these months along with other seasonal changes in aerosol processing and altitudinal distribution might have also contributed to the observed $\mathrm{S} / \mathrm{O} / \mathrm{My}$ enhancement. In particular, records of volcanic activity show that the Icelandic volcano Bárðarbunga was active August 2014 through February 2015 (Global Volcanism Program, retrieved March 2016 from http://volcano.si.edu/), which likely contributed to a shift in the dominant source and scavenging-related properties of $\mathrm{SO}_{4}^{2-}$ over the campaign that would not be representative of a typical year. Thus, the $\mathrm{SO}_{4}^{2-}$ observations of this campaign, especially the peak snow mixing ratio seen in the fall, may not reflect a seasonal trend for typical Arctic haze. The overlapping warm/cold month ranges observed for $\mathrm{Cl}^{-}, \mathrm{MS}, \mathrm{C}_{2} \mathrm{O}_{4}^{2-}$, and $\mathrm{NO}_{3}^{-}$suggest that the deposition of these chemical species was more strongly driven by factors other than nucleation, such as gasphase partitioning or other aerosol aging processes. For example, enhanced deposition of $\mathrm{MS}$ and $\mathrm{Br}^{-}$was observed as early as March and April, which could imply that their deposition was impacted by changes in the atmospheric processing of these chemical species during polar sunrise.

\section{Conclusions}

To help characterize the chemical state of the rapidly changing high Arctic, an intensive campaign of fresh snow sampling at Alert, Nunavut, was completed and snow quantified for a broad suite of analytes. Comparison of these snow measurements with coincident atmospheric measurements allowed estimation of monthly effective deposition velocities describing the total dry and wet deposition in the range of about 0.02 to $8 \mathrm{~cm} \mathrm{~s}^{-1}$. The calculated effective deposition velocities for several measured chemical species resemble those expected for dry deposition alone, suggesting that dry deposition may be the dominant removal mechanism, especially for winter scavenging of $\mathrm{BC}, \mathrm{NH}_{4}^{+}, \mathrm{SO}_{4}^{2-}, \mathrm{Na}^{+}$, 


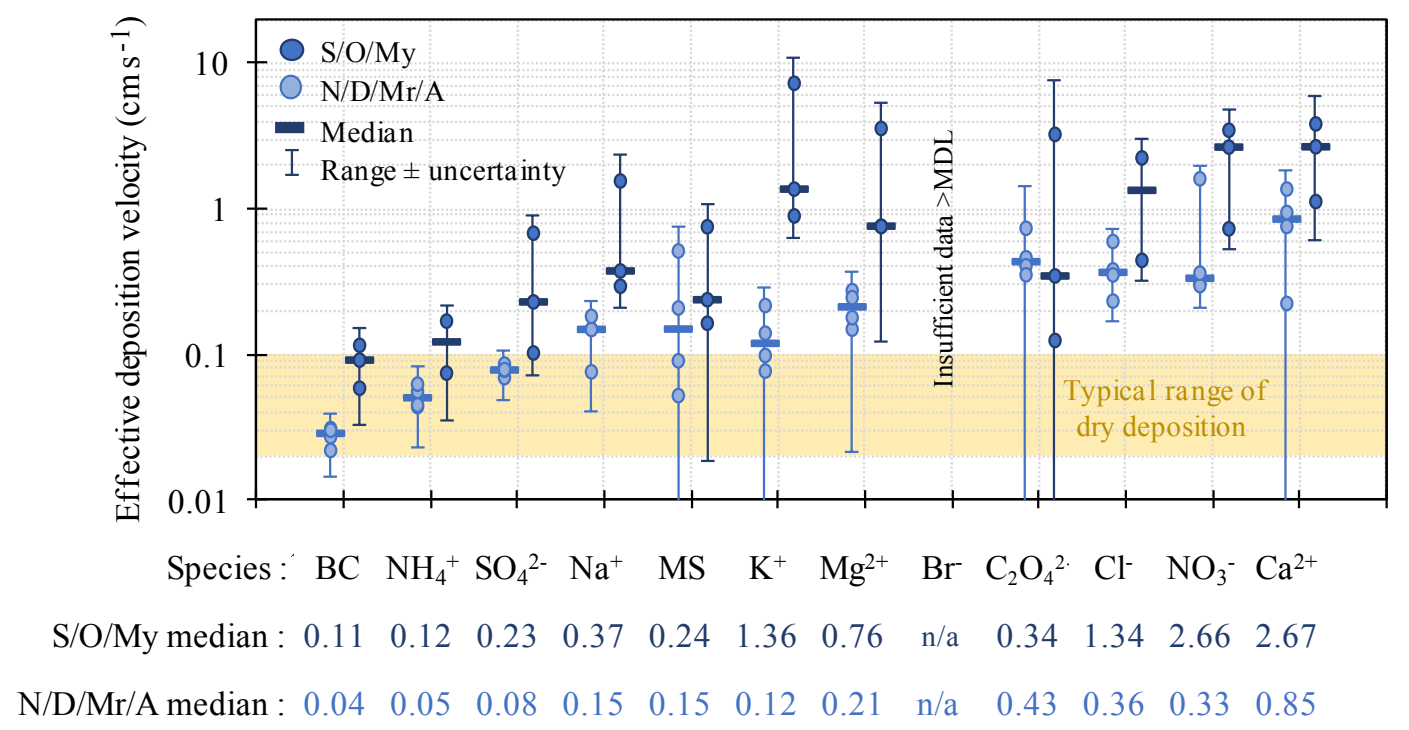

Figure 5. Effective deposition velocities split by season. The effective deposition velocities are separated into two time periods: warmer months, S/O/My (September, October, and May), and colder months, N/D/Mr/A (November, December, March, and April).

and $\mathrm{K}^{+}$. Enhanced deposition during September, October, and May suggests that wet deposition may increase in importance during these warmer months, possibly due to the presence of mixed-phase clouds and the associated scavenging of crustal, salt, and $\mathrm{SO}_{4}^{2-}$ species as $\mathrm{CCN}$; however, other factors such as changes in the dominant aerosol source profile may also contribute to the observed trend. Comparison of salt species measurements in the Arctic snow and atmosphere suggested that $\mathrm{Cl}$ experiences significant gas-phase partitioning and that this gas phase may be preferentially scavenged. Such gas-phase scavenging may contribute to the enhanced deposition of $\mathrm{MS}, \mathrm{Br}^{-}, \mathrm{Cl}^{-}$, and $\mathrm{NO}_{3}^{-}$observed relative to $\mathrm{BC}$, in conjunction with other aerosol processing differences. The low deposition velocity of BC-containing particles is consistent with those particles being externally mixed from more soluble species and having a low cloud nucleation efficiency. Given the rarity of temporally refined and broadly speciated Arctic snow sampling campaigns, measured deposition magnitudes and insights on deposition mechanisms such as these are valuable for future model validation.

Data availability. All data is provided in the Supplement.

\section{The Supplement related to this article is available online at doi:10.5194/acp-17-5775-2017-supplement.}

Author contributions. Organization of the snow collection campaign was led by Sangeeta Sharma with the assistance of Andrew Platt and sample collection by Mike Elsasser. Snow SP2 analysis was completed by Joseph R. McConnell and Nathan Chellman, snow IC analysis was led by Desiree Toom with the assis- tance of Alina Chivulescu, and snow ICP-MS was led by Katrina M. Macdonald with the assistance of Ying Duan Lei. Analysis of radiosonde data was completed by David Tarasick. Ambient atmospheric monitoring of inorganic aerosols was completed by Desiree Toom and monitoring of BC by Sarah Hanna with the assistance of Allan K. Bertram. FLEXPART simulations were completed by Heiko Bozem and Daniel Kunkel with data analysis assisted by K. Macdonald. Data interpretation was led by Katrina M. Macdonald with input and comments by all authors. Greg J. Evans and Jonathan P. D. Abbatt provided oversight for the project, including input on the manuscript.

Competing interests. The authors declare that they have no conflict of interest.

Acknowledgements. Funding of this study was provided as part of the Network on Climate and Aerosols Research (NETCARE), Natural Science and Engineering Research Council of Canada (NSERC), the government of Ontario through the Ontario Graduate Scholarship (OGS), and Environment and Climate Change Canada. This project would not have been possible without the collaboration of many skilled individuals: Richard Leaitch at Environment Canada and Catherine Philips-Smith and Cheol-Heon Jeong at the University of Toronto.

Edited by: D. J. Cziczo

Reviewed by: two anonymous referees 


\section{References}

AMAP: Snow, water, ice and permafrost in the Arctic: Climate change and the cryosphere, Arctic Monitoring and Assessment Programme, Oslo, Norway, 2011.

Banta, J. R., McConnell, J. R., Edwards, R., and Engelbrecht, J. P.: Delineation of carbonate dust, aluminous dust, and sea salt deposition in a Greenland glaciochemical array using positive matrix factorization, Geochem. Geophy. Geosy., 9, 1-19, doi:10.1029/2007GC001908, 2008.

Barrie, L. A. and Hoff, R. M.: Five years of air chemistry observations in the Canadian Arctic, Atmos. Environ., 19, 1995-2010, doi:10.1016/0004-6981(85)90108-8, 1985.

Bergin, M. H., Jaffrezo, J.-L., Davidson, C. I., Dibb, J. E ., Pandis, S. N., Hillamo, R., Maenhaut, W., Kuhns, H. D., and Makela, T.: The contributions of snow, fog, and dry deposition to the summer flux of anions and cations at Summit, Greenland, J. Geophys. Res.-Atmos., 100, 16275-16288, doi:10.1029/95JD01267, 1995.

Bond, T. C., Doherty, S. J., Fahey, D. W. et al.: Bounding the role of black carbon in the climate system: A Scientific assessment, J. Geophys. Res.-Atmos., 118, 5380-5552, doi:10.1002/jgrd.50171, 2013.

Brock C. A., Cozic, J., Bahreini, R. et al.: Characteristics, sources, and transport of aerosols measured in spring 2008 during the aerosol, radiation, and cloud processes affecting Arctic Climate (ARCPAC) Project, Atmos. Chem. Phys., 11, 2423-2453, doi:10.5194/acp-11-2423-2011, 2011.

Davidson, C. I., Lindberg, S. E., Schmidt, J. A., Cartwright, L. G., and Landis, L. R.: Dry deposition of sulfate onto surrogate surfaces, J. Geophys. Res., 90, 2123-2130, doi:10.1029/JD090iD01p02123, 1985a.

Davidson, C. I, Santhanam, Fortmann, S. R. C., and Marvin, P. O.: Atmospheric transport and deposition of trace elements onto the Greenland ice sheet, Atmos. Environ., 19, 2065-2081, 1985b.

Davidson, C. I., Honrath, R. E.. Kadane, J. B., Tsay, R. S., Mayewski, P. A. Lyons, W. B., and Heidam, N. Z.: The Scavenging of atmospheric sulfate by Arctic snow, Atmos. Environ. A, 21, 871-882, doi:10.1016/0004-6981(87)90083-7, 1987.

Davidson, C. I., Jaffrezo, J.-L., Mosher, B. W., Dibb, J. E., Borys, R. D., Bodhaine, B. A., Rasmussen, R. A., Rasmussen, R. A., Boutron, C. F., Gorlach, U., Cachier, H., Ducret, J., Colin, J. L., Heidam, N. Z., Kemp, K., and Hillamo, R.: Chemical constituents in the air and snow at Dye 3, Greenland: I. Seasonal variations, Atmos. Environ. A, 27, 2709-2722, doi:10.1016/0960-1686(93)90304-H, 1993.

Dibb, J. E., Whitlow, S. I., and Arsenault, M.: Seasonal variations in the soluble ion content of snow at Summit, Greenland: Constraints from three years of daily surface snow samples, Atmos. Environ., 41, 5007-5019, doi:10.1016/j.atmosenv.2006.12.010, 2007.

Farmer, D. K., Cappa, C. D., and Kreidenweis, S. M.: Atmospheric processes and their controlling influence on cloud condensation nuclei activity, Chem. Rev., 115, 4199-4217, doi:10.1021/cr5006292, 2015.

Hagler, G. S. W., Bergin, M. H., Smith, E. A., and Dibb, J. E.: A Summer time series of particulate carbon in the air and snow at Summit, Greenland, J. Geophys. Res.-Atmos., 112, 1-12, doi:10.1029/2007JD008993, 2007.

Hansen, A. D. A. and Rosen, H.: Vertical distributions of particulate carbon, sulfur, and bromine in the Arctic haze and comparison with ground-level measurements at Barrow, Alaska, Geophys. Res. Lett., 11, 381-84, doi:10.1029/GL011i005p00381, 1984.

Harder, S. L., Warren, S. G., Charlson, R. J., and Covert, D. S.: Filtering of air through snow as a mechanism for aerosol deposition to the Antarctic ice sheet, J. Geophys. Res., 101, 18729-18743, doi:10.1029/96JD01174, 1996.

Hartmann, D. J., Klein Tank, A. M. G., Rusticucci, M., Alexander, L. V., Brönnimann, S., Charabi, Y. A.-R., Dentener, F. J., Dentener, F. J., Dlugokencky, E. J., Easterling, D. R., Kaplan, A., Soden, B. J., Thorne, P. W., Wild, M., and Zhai, P.: Observations: Atmosphere and surface, Climate change 2013: The Physical science basis, Contribution of working group I to the fifth assessment report of the Intergovernmental Panel on Climate Change, edited by: Stocker, T. F., Qin, D., Plattner, G.-K., Tignor, M., Allen, S. K., Boschung, J., Nauels, A., Xia, Y., Bex, V., and Midgley, P. M., Cambridge University Press, Cambridge and New York, NY, doi:10.1017/CBO9781107415324.008, 2013.

Hicks, B. B.: Measuring dry deposition: A Re-assessment of the state of the art, Water Air Soil Poll., 30, 75-90, doi:10.1007/BF00305177, 1986.

Hillamo, R. E., Kerminen, V.-M., Maenhaut, W., Jaffrezo, J.-L., Balachandran, S., and Davidson, C. I.: Size distributions of atmospheric trace elements at Dye 3, Greenland: I. Distribution characteristics and dry deposition velocities, Atmos. Environ. A, 27, 2787-2802, doi:10.1016/0960-1686(93)90311-L, 1993.

Hoose, C. and Möhler, O.: Heterogeneous ice nucleation on atmospheric aerosols: A Review of results from laboratory experiments, Atmos. Chem. Phys., 12, 9817-9854, doi:10.5194/acp12-9817-2012, 2012.

Ibrahim, M., Barrie, L. A., and Fanaki, F.: An Experimental and theoretical investigation of the dry deposition of particles to snow, pine trees and artificial collectors, Atmos. Env., 17, 781-88, doi:10.1016/0004-6981(83)90427-4, 1983.

Law, K. S. and Stohl, A.: Arctic air pollution: Origins and impacts, Science, 315, 1537-1540, doi:10.1126/science.1137695, 2007.

Leaitch, W. R., Hoff, R. M., and MacPherson, J. I.: Airborne and lidar measurements of aerosol and cloud particles in the troposphere over Alert Canada in April 1986, J. Atmos. Chem., 9, 187-211, doi:10.1007/BF00052832, 1989.

Legrand, M. and De Angelis, M.: Origins and variations of light carboxylic acids in polar precipitation, J. Geophys. Res., 100, 1445-1462, doi:10.1029/94jd02614, 1995.

Liu, J., Fan, S., Horowitz, L. W., and Levy, H.: Evaluation of factors controlling long-range transport of black carbon to the Arctic, J. Geophys. Res., 116, D04307, doi:10.1029/2010JD015145, 2011.

McConnell, J. R., Edwards, R., Kok, G. L., Flanner, M. G., Zender, C. S., Saltzman, E. S., Banta, J. R., Pasteris, D. R., Carter, M. M., and Kahl, J. D. W.: 20th-Century industrial black carbon emissions altered Arctic climate forcing, Science, 317, 1381-1384, doi:10.1126/science.1144856, 2007.

McMahon, T. A. and Denison, P. J.: Empirical atmospheric deposition parameters: A Survey, Atmos. Environ., 13 571-585, doi:10.1016/0004-6981(79)90186-0, 1979.

Morrison, H., Shupe, M. D., Pinto, J. O., and Curry, J.: Possible roles of ice nucleation mode and ice nuclei depletion in the extended lifetime of Arctic mixed-phase clouds, Geophys. Res. Lett., 32, 1-5, doi:10.1029/2005GL023614, 2005.

Nguyen, Q. T., Skov, H., Sørensen, L. L., Jensen, B. J., Grube, A. G., Massling, A., Glasius, M., and Nøjgaard, J. K.: Source ap- 
portionment of particles at Station Nord, north east Greenland during 2008-2010 using COPREM and PMF analysis, Atmos. Chem. Phys., 13, 35-49, doi:10.5194/acp-13-35-2013, 2013.

Norris, G., Duvall, R., Brown, S., and Bai. S.: EPA Positive matrix factorization (PMF) 5.0 fundamentals and user guide, US Environmental Protection Agency, 2014.

Paris, J.-D., Stohl, A., Nédélec, P., Arshinov, M. Yu., Panchenko, M. V., Shmargunov, V. P., Law, K. S., Belan, B. D., and Ciais, P.: Wildfire smoke in the Siberian Arctic in summer: source characterization and plume evolution from airborne measurements, Atmos. Chem. Phys., 9, 9315-9327, doi:10.5194/acp-9-9315-2009, 2009.

Petroff, A. and Zhang, L.: Development and validation of a size-resolved particle dry deposition scheme for application in aerosol transport models, Geosci. Model Dev., 3, 753-769, doi:10.5194/gmd-3-753-2010, 2010.

Pytkowicz, R. M. and Kester, D. R.: The Physical chemistry of sea water, Oceanogr. Mar. Biol., 9, 11-60, doi:10.1029/WR001i002p00263, 1971.

Quinn, P. K., Shaw, G., Andrews, E., Dutton, E. G., RuohoAirola, T., and Gong, S. L.: Arctic haze - Current trends and knowledge gaps, Tellus B, 59, 99-114, doi:10.1111/j.16000889.2006.00238.x, 2007.

Quinn, P. K., Bates, T. S., Schulz, K., and Shaw, G. E.: Decadal trends in aerosol chemical composition at Barrow, AK: 19762008, Atmos. Chem. Phys., 9, 18727-18743, doi:10.5194/acpd9-18727-2009, 2009.

Reff, A., Eberly, S. I., and Bhave, P. V.: Receptor modeling of ambient particulate matter data using positive matrix factorization: Review of existing methods, J. Air Waste Manag. Assoc., 57, 146-154, doi:10.1080/10473289.2007.10465319, 2007.

Rigor, I. G., Colony, R. L., and Martin, S.: Variations in surface air temperature observations in the Arctic: 1979-1997, J. Clim., 13, 896-914, doi:10.1175/15200442(2000)013<0896:VISATO>2.0.CO;2, 2000.

Schroder, J. C., Hanna, S. J., Modini, R. L., Corrigan, A. L., Kreidenwies, S. M., MacDonald, A. M., Noone, K. J., Noone, K. J., Russell, L. M., Leaitch, W. R., and Bertram, A. K.: Sizeresolved observations of refractory black carbon particles in cloud droplets at a marine boundary layer site, Atmos. Chem. Phys., 15, 1367-1383, doi:10.5194/acp-15-1367-2015, 2015.

Sehmel, G. A.: Particle and gas dry deposition: A Review, Atmos. Environ., 14, 983-1011, doi:10.1016/0004-6981(80)90031-1, 1980.
Seinfeld, J. H. and Pandis, S. N.: Atmospheric chemistry and physics - From Air pollution to climate change, Wiley, Michigan, USA, 2006.

Sharma, S., Ishizawa, M., Chan, D., Lavoué, D., Andrews, E., Eleftheriadis, K., and Maksyutov, S.: 16-Year simulation of Arctic black carbon: Transport, source contribution, and sensitivity analysis on deposition, J. Geophys. Res-Atmos., 118, 943-964, doi:10.1029/2012JD017774, 2013.

Shupe, M. D., Matrosov, S. Y., and Uttal, T.: Arctic mixed-phase cloud properties derived from surface-based sensors at SHEBA, J. Atmos. Sci., 63, 697-711, doi:10.1175/JAS3659.1, 2006.

Sirois, A. and Barrie, L. A.: Arctic lower tropospheric aerosol trends and composition at Alert, Canada: 1980-1995, J. Geophys. Res., 104, 11599-11618, doi:10.1029/1999JD900077, 1999.

Spackman, J. R., Gao, R. S., Neff, W. D., Schwarz, J. P., Watts, L. A., Fahey, D. W., Holloway, J. S., Holloway, J. S., Ryerson, T. B., Peischl, J., and Brock, C. A.: Aircraft observations of enhancement and depletion of black carbon mass in the springtime Arctic, Atmos. Chem. Phys., 10, 9667-9680, doi:10.5194/acp10-9667-2010, 2010.

Stohl, A., Forster, C., Frank, A., Seibert, P., and Wotawa, G.: Technical note - The Lagrangian particle dispersion model FLEXPART version 6.2, Atmos. Chem. Phys., 5, 2461-2474, doi:10.5194/acp-5-2461-2005, 2005.

Stroeve, J. C., Serreze, M. C., Fetterer, F., Arbetter, T., Meier, W., Maslanik, J., and Knowles, K.: Tracking the Arctic's shrinking ice cover: another extreme September minimum in 2004, Geophys. Res. Lett., 32, 1-4, doi:10.1029/2004GL021810, 2005.

Toom-Sauntry, D. and Barrie, L. A.: Chemical composition of snowfall in the high Arctic: 1990-1994, Atmos. Environ., 36, 2683-2693, doi:10.1016/S1352-2310(02)00115-2, 2002.

Zhang, L. and Vet, R.: A Review of current knowledge concerning size-dependent aerosol removal, China Part., 4, 272-282, doi:10.1016/S1672-2515(07)60276-0, 2006.

Zobrist, B., Marcolli, C., Koop, T., Luo, B. P., Murphy, D. M., Lohmann, U., Zardini, A., Zardini, A., Krieger, U. K., Corti, T. Cziczo, D. J., Fueglistaler, S., Hudson, P. K., Thomson, D. S., and Peter, T.: Oxalic acid as a heterogeneous ice nucleus in the upper troposphere and its indirect aerosol effect, Atmos. Chem. Phys., 6, 3115-3129, doi:10.5194/acpd-6-3571-2006, 2006. 